\title{
THE INFLUENCE OF MARKET ATTRACTIVENESS AND RESOURCE CAPABILITIES AGAINST THE PRIMACY OF THE AIRLINES IN INDONESIA
}

\author{
Suharto Abdul Majid", Charles An², Mohammad Iqbal Firdaus ${ }^{3}$
}

1. STMT Trisakti, 2. STMT Trisakti, 3. STMT Trisakti

corresponding author : samtrisakti1531@gmail.com

\begin{abstract}
This research aims to analyze the influence of market attractiveness and resource capabilities against the primacy of the airlines in Indonesia. The unit of analysis in this research is the national airline company in Indonesia with the unit of observation is the leadership of the national aviation company. The research was based on the nature of the cross sectional time coverage in the year 2016. The research method used is descriptive and verifikatif with data analysis using Structural Equation Modeling (SEM)-based Partial Least Square (PLS). The test results showed that the attractiveness of the market and resource capabilities together to the primacy of aviation companies in Indonesia, while partially resource capabilities do not affect advantage aviation company.
\end{abstract}

Keywords: attractiveness of market, resources, capabilities and primacy of the airlines.

\section{Introduction}

The primacy of airlines in Indonesia is relatively low compared to those of other countries. In 2015 and 2016, punctuality aspect of national airlines is still below 80 percent. Not a single national airline has listed the Top 20 Airlines by OTP 2016 (OAG Punctuality League 2016 and 2017). Similarly in the low cost carrier category, none of the LCC airlines from Indonesia is in the Top 20 Airlines by OTP.

From profitability aspect, the same situation applies where there is no national airlines has been included in the Top 10 Economic Profit Generators by Dollar in 2011-2015 and Top 10 Economic Profit Generators by Percentage Margin Over Their 5-Years Revenue Year 2011-2015 by LEK Aviation Insights Review 2016.

From the aspect of aviation safety, the reputation is still relatively unfavorable as shown by the issuance of the flight ban by the EU aviation authority on the Indonesian national airlines flying to Europe in the period 2007 s.d. 2015 as a 
result of frequent aviation accidents in 2004-2007. Furthermore, the Federal Aviation Adminstration (FAA) also rated Indonesian carriers in the second rank which means unsafe. No national airlines have entered the Top 20 Safest Airlines 2016-2017 by Airlines Rating.com and Aviation-Safety.net.

The tight competition among airlines leading to price war greatly affects airline yields and sharp fluctuation, especially for less professionally and inefficiently managed airlines which will lose direction in implementing strategy and controlling the company resulting in low yield. On the other hand, operational costs do not decrease even tends to increase and revenue in rupiah decreases affected by the high USD exchange rate against IDR (Martono et al 2016 and Simarmata et al 2016).

This condition illustrates that the domestic airline's primacy is still not optimal, especially regarding product quality as reflected in the quality of service in general, on-time performance, as well as the lack of innovations made by the airline so far, fluctuation of business growth, and less favorable image of the airlines among the public.

Growth in the number of passengers transported by air has continued to rise sharply since 2004 and. 2015 to reach 90.6 million in 2015 consisting of passengers with low cost, full service carriers, and Garuda Indonesia.

Based on the description, it is evident that the aviation market in Indonesia, both domestic and international markets continue to grow positively (Abdul Majid et al 2016)

The market share of domestic and international air passengers achieved by national airlines during 2010-2014 shows the growth of domestic and overseas passengers in Indonesia during 2005-. 2014. The number reached in 2014, 270 serving 114 cities and 164 pioneer routes connecting 146 isolated areas across the archipelago.

This study is based on the theory of market attractiveness, resource capability, and corporate excellence in aviation cases. This study includes the works by Firsan Nova (2014), Best (2009), Cravens and Piercy (2003), Walker, Boyd, 
and Larreche (1992). We also examined the capabilities of resources such as Barney and Clark (2007), Amit and Schoemaker (1993), and Cigler (2007). Furthermore, we examine the benefits of the company include Chen \& Chang (2013), Collis and Montgomery (1998, 2005), Rozemeijer (2000, 2003), Chai, et al. (2006), Victor Tang and Roy Bauer (1995), Kusumasari, Alam, and Siddiqiu (2010).

\section{Method}

This study is descriptive with explanatory survey. The data collected is analyzed using PLS-based SEM.

The population in this study is all national airlines in Indonesia, both scheduled and scheduled non-scheduled flights operating in Indonesia. The observation unit in this study is the top flight leaders representing each airline. Methods of data collection were conducted through questionnaires and the use of qualitative analysis with in-depth interviews to support quantitative analysis.

\section{Discussion and Result}

The hypothesis testing of the effect of market attractiveness and resilience capability on the company's primacy either simultaneously or partially using PLS 2.0 can be described as follows:

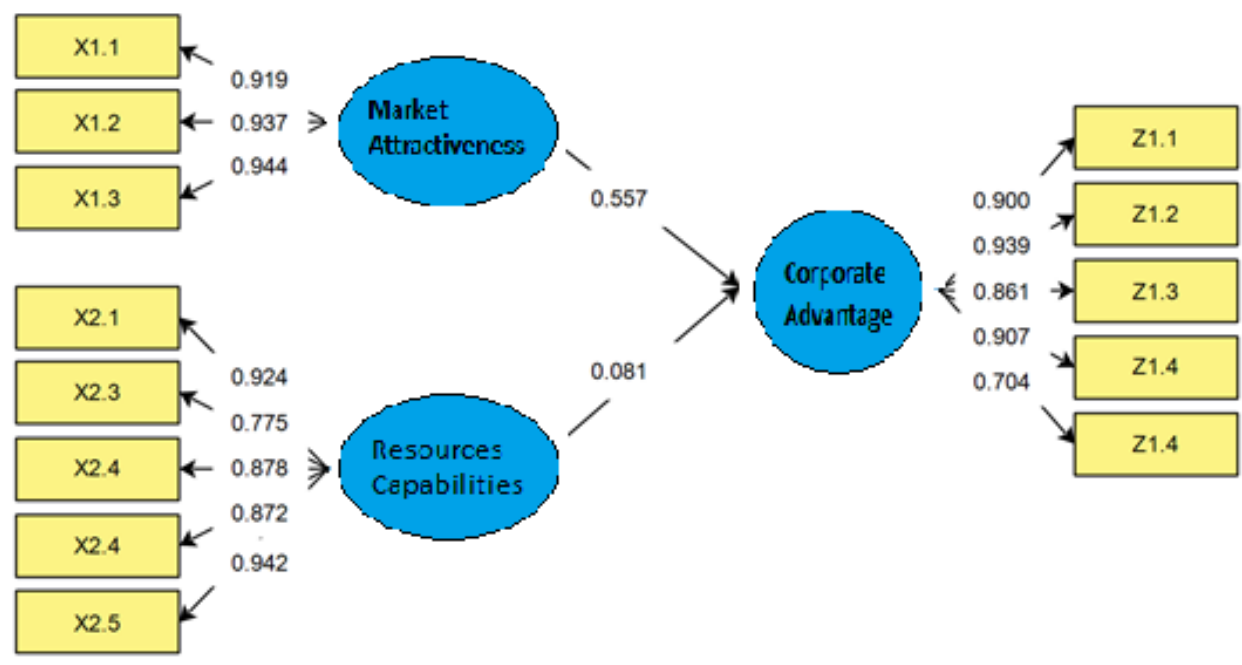

Figure 1. Path diagram of the hypothesis 
The structural model for diagram in Figure 1 is as follows: $\boldsymbol{\eta}_{\mathbf{1}}=\mathbf{0 . 5 5 7} \xi_{1+}$

$0.081 \xi_{2}+\zeta_{2}$

Tabel 1. Results of Simultaneous and Partial Hypothesis Testing

\begin{tabular}{|c|c|c|c|c|c|c|}
\hline Hypothesis & $\begin{array}{c}\text { F } \\
\text { Acount }\end{array}$ & $\gamma$ & SE & T Statistics & $\mathbf{R}^{2}$ & Remark \\
\hline $\begin{array}{l}\text { Market attractiveness } \\
\text { and resource capability } \\
\rightarrow \text { Corporate Advantage }\end{array}$ & $82.93 *$ & & & & 0.860 & Significant \\
\hline $\begin{array}{l}\text { Market attractiveness } \rightarrow \\
\text { Corporate Advantage }\end{array}$ & & 0.557 & 0.134 & $4,153^{*}$ & 0.763 & Significant \\
\hline $\begin{array}{l}\text { resource capability } \rightarrow \\
\text { Corporate Advantage }\end{array}$ & & 0.081 & 0.141 & 0,571 & 0.335 & $\begin{array}{c}\text { Not } \\
\text { Significant }\end{array}$ \\
\hline
\end{tabular}

* Significant $\alpha=0.05$

Source: Primary data, 2017

Simultaneous Effect

The hypothesis tested is the simultaneous effect of market attractiveness and resource capability to company's primacy. The test conducted by $\mathrm{F}$ test with $\mathrm{F}$ calculated value obtained using the following formula.

$F=\frac{(n-k-1)\left(R^{2}\right)}{k\left(1-R^{2}\right)}$

$F=\frac{(30-2-1)(0,860)}{2(1-0,860)}$

$\mathrm{F}$ acount $=82,928$

By $\alpha=5 \%$ dan df $1=k=2$, df $2=n-k-1=30-2-1=27$ retrived value $\mathrm{F}$ table of $\pm 3,354$.

The analysis shows the F-count value of 82.928. Since the value of F arithmetic (82.928)> F table (3.354), therefore the hypothesis is accepted that is market 
attractiveness and resource capability simultaneously affect the company's primacy in Indonesia aviation industry.

\section{Partial Effect}

The hypothesis tested is the effect of market attractiveness to company's primacy. Based on the results presented in Table 1, it can be seen the path coefficient of market attractiveness variable to the company's primacy of 0.557 with a positive direction. That is, the higher the market attractiveness the more improved the company's primacy. This hypothesis is accepted as shown by t value of 4.153> 1.96 (5\% significance level) which means that the test results are significant. That is, market attractiveness has a significant effect on the company's primacy in the aviation industry in Indonesia.

Next is the test of the effect of resource capability on the company's primacy. Based on the results as presented in Table 1, it can be seen the path coefficient of variable resource capability to the company's primacy of 0.081 with a positive direction. That is, the higher the resource capability the more in increase of the company's capability. This hypothesis is rejected as indicated by a t value of $0.571<1.96(5 \%$ significance level) which means the test result is insignificant. That is, the capability of resources has no significant effect on the company's primacy in the aviation industry in Indonesia.

\section{Result and Discussion}

The result of hypothesis testing of market attractiveness have a significant effect to company's advantage is in accordance with previous study by Nova (2014). She indicates that there is significant relationship and influence between market attractiveness with corporate primacy. This relationship can be explained also by the fact that a market that has various potentials and successfully captured by the company as an opportunity to make the company win the competition because it becomes the leader and allows to set the shape and direction of competition in the future. Appropriate analysis along with less attention given by competitors to the target market allows companies to allocate resources effectively and efficiently to generate profits. 
The market attractiveness of the three dimensions of market potential, competition intensity, and market access that the average high score in the domestic aviation market in Indonesia has effectively been able to realize the benefits of national airlines. That is, the creation of the benefits of airlines is influenced and shaped by the high attractiveness of the existing market, so that domestic airlines in Indonesia are expected to compete and develop well.

In general, the condition of the capability of Indonesian domestic airlines resources as reflected by the responses of airline leaders indicates that it is good, although out of five, there are two dimensions, financial and technological, that score low. Financial in this context is related to financial performance such as profitability level, maximal profit achievement, income, efficiency, and solvency or liquidity of assets while technology is related to the application of appropriate technology, technological innovation, and technology adaptation.

The conclusion drawn from the interviews with airline leaders indicates that human resources have an important and strategic role so that human resources must be empowered, optimized, and enhanced their competence and productivity for enterprise progress.

Considering the conclusion, the impression of the commitment and attention of airline leadership on the effort to empower and optimize the role of human resources is very high, but the study indicates that there has not $\mathrm{t}$ shown capability and high quality in human resources aspect yet. As a result, what needs to be done in the future is to ensure the existence of harmony between commitment and implementation of human resources improvement.

Based on the results obtained the partial influence of resource capability variable to corporate primacy variable is not significant, this has become a finding because based on in-depth interviews with some key informant leaders and business practitioners and leaders of the Indonesian national airline association, there are some drawn conclusion as follows : 
1. The first thing in the aviation business in Indonesia is the market factor. The high market attractiveness factor is the trigger for growth and development of aviation business in Indonesia. In business, the commercial air transport sector will grow when the market is attractive, positive economic growth and development, and trade.

2. To achieve this needs synergy, coordination and collectivity. This cannot in isolation and requires the most important condition of market prospect. Capability of resources cannot work individually, but it has to coordinate and work together with other elements within the company to manage and pack the market attractiveness at the optimum level for future primacy of the airline.

This is in line with Protogerou, Caloghirou and Loukas (2007) suggesting that resource capacity now emphasizes the ability to change and adapt quickly in support of corporate excellence; Cardeal and Antonio (2012) who argue that a resource can be said to have value when that resource can enable a company to implement a strategy to improve its efficiency and effectiveness. A resource will not be said to be valuable when used inefficiently. The value of the resource is still latent until the company has the ability to exploit it.

In analyzing the partial influence of capability on the company's primacy in the aviation industry in Indonesia, the dimensions in the capability of resources are financial, technology, leadership, institution, and human resources. Two dimensions scoring the lowest are finance and technology while the dimensions of corporate excellence variables, the two dimensions that score low among these are price and innovation.

In response to this, key informants stated the facts on the ground the financial condition of the Indonesian national airline is not in good condition which airline managers tend to cover the actual financial condition. Associated with technology, he said the national aviation business lacks of technological innovation for the utilization of company resources. In terms of price dimensions and innovation in the variable of corporate excellence, national airlines generally compete to offer cheaper tariffs and the company is still 
lacking in terms of innovation. Key informants focus more on the overall quality of the five dimensions of resource capability that is generally less positive, especially regarding the leadership dimension that plays an important role to manage and mobilize other resources.

Key informants also highlighted the leadership aspect of a number of national airlines which, according to him, did not yet have effective or strong leadership. Only a few companies have indicated strong leadership, eg leadership in the company of Lion Air and Sriwijaya Air.

According to the key informant the current airline's leadership profile is largely devoid of complete managerial stages in an airline, thus lacking in comprehension and understanding of resource capability issues and how to achieve corporate excellence.

Keywords in this case, leadership is a strategy about the decision-making process. A leader must be able to build a strategy by utilizing various resources of the organization and apply them appropriately to achieve the company's advantage. A leader must be able to read the highly dynamic and rapidly changing aviation industry's strategic environment.

It is understandable that in the case of Indonesia's domestic aviation industry, where Ismail, Rose, Uli, and Abdullah (2012) argue about the relationship between resource capability and corporate advantage: "the level of competitive advantage of firms that matches business competition, its internal strengths and weaknesses with its potential influence on excellence"bhave not been well accommodated. Similarly, the opinions of Jeroen Kraaijenbrink, JC Spender and Aard J. Groen (2010) on "internal resources indicate a relationship to the competitive advantage of the organization" in the case of this study are not accommodated well.

\section{Conclusion}

Market attractiveness and resource capability simultaneously have a positive and significant impact on the company's advantage in the aviation industry in Indonesia, but partially the resource capability has no effect on the company's 
primacy.

The variable of resource capability has no positive and significant effect to company's capacity. The empirical factual findings indicate that of the five dimensions of resource capability, the two dimensions of relatively low values are finance and technology, and are in accordance with the confirmation of qualitative research results which reinforce both dimensions relatively are low. The findings related to the leadership dimension are also considered relatively low or not shown strong or effective leadership in the aviation business in Indonesia. Empowerment of resource capability has not been done synergistically and integrated resulting in inability to utilize and manage market attractiveness effectively.

\section{References}

Abdul Majid, Suharto, Kaltum, Umi, and Sucherly. 2016. Analysis on the Factors Causing Airlines Bankruptcy: Case in Indonesia. International Journal of Management Science and Business Research Vol 5 Issue 2.

Abdul Majid, Suharto. 2017. Potret Transportasi Indonesia:Bandar Udara dan Keterlambatan Penerbangan di Indonesia. Editor Darmaningtyas. Jakarta: Hegel Pustaka dan MTI.

A. Hitt, Michael; E. Hoskisson, Robert; Ireland, R.Duane. 2007. Management of Strategy. Thomson, South-Western.

Aviation Insights Review (AIR): 2017 Global Airline Industry Performance Update Volume XIX Issue 29. LEK Consulting LLC. www.aviation@lek.com (diunduh tgl 26 April 2017)

Best, Roger J., 2005. Market-Based Management. Prentice Hall, Upper Saddle River

Cardeal, Nuno and António, Nelson. 2012. Valuable, Rare, Inimitable Resources and Organization(VRIO) Resources or Valuable, Rare, Inimitable Resources(VRI) Capabilities: What Leads to Competitive Advantage? African Journal of Business Management Vol. 6(37), pp. 10159-10170, 19 September

Collis, David J,\& Cynthia A. Montgomery. 1998. How Can You Tell if Your Company is Really more than the Sum of Its parts! Creating Corporate Advantage. Havard Bussiness Review:72-73.

Chen, Yu-San and Chang, Ching-Hsun. 2013. Towards Green Trust: The Influences of Green Perceived Quality, Green Perceived Risk, and Green Satisfaction. Journal of Management Decision Vol 51 Issue 1 pp 63-82 
Cravens, W. David \& Piercy, F. Nigel. 2009. Strategic Marketing Ninth Edition. New York: McGraw Hill dan Vijay, A. (2005 )). Management Control System Edisi 11. Jakarta: Salemba Empat.

Ditjen Hubud. 2007a. Hasil Penilaian Kinerja Bandar Udara.www.dephub.go.id, (13 Jun) pp.1

Ditjen Hubud. 2007b. Keselamatan dan Keamanan Penerbangan adalah Hal yang Utama. www.dephub.go.id, (27 Apr), pp.1.

Doganis, R. 2006.The Airlines BusinessSecond Edition. Routledge, 2 Park Square, Milton Park, Abingdon, Oxon, Canada: Routledge

Gudmundsson, S.V; \& C. Lechner. 2006. Multilateral airline alliances: Balancing strategic constraints and opportunities.Journal of Air Transport Management (12) pp. 153-158.

Hitt, A. Michael, Ireland, R. Duane, \& Hoskisson, E. Robert. 1997. Manajemen Strategis Menyongsong Era Persaingan dan Globalisasi. Alih Bahasa Armand Hediyanto (UI). Jakarta: Penerbit Erlangga

INACA. 2014. Annual Report of Indonesia National Air Carrier Association 2014. Jakarta: INACA.

INACA. 2015. Annual Report of Indonesia National Air Carrier Association 2015. Jakarta: INACA.

Ismail, A. I., Rose, R. C., Uli, J., \& Abdullah, H. 2012.The Relationship Between Organisational Resources, Capabilities, Systems and Competitive Advantage. Asian Academy of Management Journal, 17(1), 151-173.

Kusumasari, Bevaola, Alam, Quamrul, Siddiqiu, Kamal. 2010. Resources Capabilty for Local Government in Managing Disasters. Journal of Disaster Prevention and Management Vol 19 No 4 pp. 438-451

Manurung, Laurensius. 2010. Strategi dan Inovasi Model Bisnis Meningkatkan Kinerja Studi Empiris Industri Penerbangan. Jakarta: Elex Media Komputindo.

Martono, Kemis, Marina, Sandriana, and Wardana, Aditya. 2016. Domestic Air Transport Regulations in Indonesia. Jurnal Manajemen Transportasi \& Logistik Vol 03 No 1.

Narver, J. \&. Slate, S. 1990. The Effect of a Market Orientation on Business Performance. Journal of Marketing 5(3)pp20-35.

OAG Aviation Punctuality League 2017. Annual On-Time Performance Results for Airlines and Airport 2017. www.oag.com (downloaded on April 25, 2017).

ICAO Universal Safety Oversight Audit Program 2014 for Indonesia. www.icao.int/safety/Pages/USOAP-Results.aspx (downloaded on April 28, 2017)

Pearce II, J.A., dan Robinson, R.B. 2011. Strategic Management: Formulation, Implementation and Control. New York: McGraw Hill

Rozemeijer, Frank Adrian. 2003. Creating Corporate Advantage in Purchasing. Technische Universiteit Eindhoven: The Journal of Supply Chain Management January 2003 
Saeedi, N., Nabilou, H., Masouleh, S. A., \& Beikkhakhian, Y. 2012. A review on Iran's carpet Industry situation in international markets. African Journal of Business Management, 6(30), 8902-8909.

Sauerhoff, C. 2014. Competitive Differentiation within the Shipbuilding Industry: The Importance of Competence in the Field of Services. Springer Gabler.

Seoudi, Imam. 2009. The Resource-Capability-Competence Perspective in Strategic Management: A Re-Appraisal of the Epistemological \& Theoritical Foundations. Department of Economics Case Western Reserve University, January 2009 UMI Microform 3339941

Slater, S. \& Narver, J. 1994. Does Competitive Environment Moderate the Market Orientation - Performance Relationship? Journal of Marketing 58pp46-55.

Simarmata, Juliater, RS, Marthaleina, Keke, Yulianti, and Panjaitan, Ferry. 2016. The Airlines Customer's Buying Decision Throught Online Travel Agent: A Case Study of The Passengers of Scheduled Domestic Airline in Indonesia. International Journal of Economics, Commerce, and Management Vol IV Issue 3.

Steinenger, D. M., Huntgeburth, J. C., \& Veit, D. J. 2011. Conceptualizing Business Models for Competitive Advantage Research by Integrating the Resource and Market-Based Views. AMCIS 2011.

Thomas, John and Catlin, Brett. 2014. Aviation Insights Review: The Future of Airlines Business Model - Which will Win? Singapore: LEK Consulting LLC

www.airlineratings.com (downloaded on April 27,2017)

www.aviation-safety.net (downloaded on April 27, 2017) 